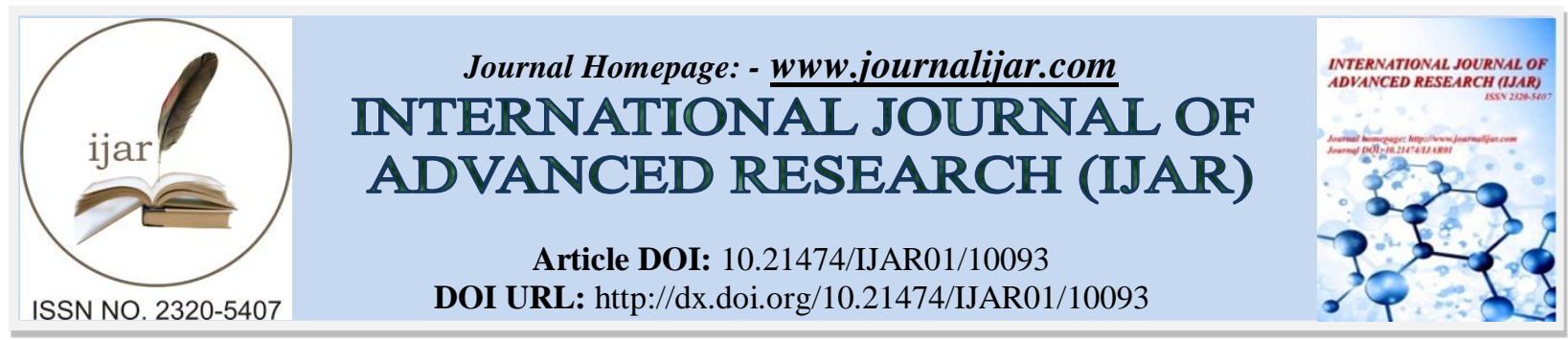

RESEARCH ARTICLE

\title{
DIETARY FIBRE AND VITAMIN E CONTENTS OF FIVE CUCURBITACEAE OILSEEDS FROM DIFFERENT REGIONS IN CAMEROON.
}

\author{
M. B. Achu Loh $^{1}$,R. A. Yiagnigni ${ }^{1}$, G. Yadang Souley ${ }^{2}$, E. Fokou ${ }^{1}$, E. A. Panyo ${ }^{2}$, G. Kansci ${ }^{1}$, L. Ribourg ${ }^{3}$ and $^{2}$ \\ C. Genot ${ }^{3}$. \\ 1. Department of Biochemistry, Faculty of Science, P.O. Box 812, University of Yaoundé I, Cameroon. \\ 2. Centre for Research in Food and Nutrition, IMPM, Yaoundé, Cameroon. \\ 3. UR1268 BIA (Biopolymères Interactions Assemblages), INRA, 44300 Nantes, France.
}

\section{Manuscript Info}

…......................

Manuscript History

Received: 14 September 2019

Final Accepted: 16 October 2019

Published: November 2019

Key words: -

Dietary fibre, tocopherols, Cucurbit seeds.

\section{Abstract}

Dietary fibre and vitamin E levels were evaluated in five species of Cucurbit oilseeds (Cucumeropsis mannii, Cucurbita maxima, Cucurbita moschata, Lagenaria siceraria and Cucumis sativus) from different agro-ecological zones in Cameroon, to supplement the available food composition data on these seeds. The results showed that the dietary fibre and vitamin E levels did not depend on the region of origin but on the species. The seeds were rich in dietary fibre especially insoluble dietary fibre, which varied from $15.70 \pm 1.61$ (C. sativus) to $19.21 \pm$ $1.29 \mathrm{~g} / 100$ Edible Portion (EP) (C. mannii), making up $74-81 \%$ of the total dietary fibre. Soluble dietary fibre ranged from $4.35 \pm 1.18$ (C. maxima) to $6.60 \pm 0.86 \mathrm{~g} / 100 \mathrm{~g}$ EP (L. siceraria) and total dietary fibre was from $20.19 \pm 1.81$ (C. sativus) to $25.13 \pm 1.68 \mathrm{~g} / 100 \mathrm{~g} \mathrm{EP}$ (L. siceraria). Alpha $(\alpha)$, gamma $(\gamma)$ and delta $(\delta)$-tocopherols were present in all the samples. The $\delta$ - tocopherol level was from $0.23 \pm 0.32$ (C. moschata) to $8.52 \pm 1.64$ (C. sativus), $\alpha$-tocopherol from $3.87 \pm 3.14$ (C. maxima) to $9.84 \pm 6.00$ (L. siceraria) and gamma $(\gamma)$ tocopherol from $87.12 \pm 39.42$ (C. moschata) to $644.86 \pm 130.50 \mu \mathrm{g} / \mathrm{g}$ of lipid (L. siceraria), making up $94-99 \%$ of total tocopherols in these seed oils. Total tocopherols were from $92.72 \pm 42.19$ (C. moschata) to $662.03 \pm$ $134.33 \mu \mathrm{g} / \mathrm{g}$ of lipid (L. siceraria). Consumption of $100 \mathrm{~g}$ of these seeds (especially L. siceraria), can cover the dietary fibre needs per day for children of $1-8$ years old, women and $70 \%$ in men and the vitamin E needs per day for all age groups. The dietary fibre and vitamin $\mathrm{E}$ (antioxidants) levels in these seeds suggest their potential to fight against overweight, obesity and oxidative stress, preventing cancer. L. siceraria oil could also be added to palm oil during hot treatment, as antioxidant, to increase its stability by preventing free fatty acids from heat oxidation.

Copy Right, IJAR, 2019,. All rights reserved.

\section{Introduction:-}

In many countries, economic development is closely linked to the health status of the population. The main challenge is to improve the global human health status without increasing expenditure on health. Non-communicable

Corresponding Author:- M. B. Achu Loh.

Address:-Department of Biochemistry, Faculty of Science, P.O. Box 812, University of Yaoundé I, 
illnesses like type II diabetes mellitus, cancers and cardiovascular diseases, partly linked to inappropriate diet, are increasing in developing countries. In Cameroon, between 2000 and 2012, the percentages of total death linked to these illnesses were $2 \%, 3 \%$ and $11 \%$ respectively (WHO, 2014). Insufficient knowledge on the nutritional composition of available foodstuffs and their health benefits, alongside low income, are some of the causes of low consumption of nutrient-rich foods and of malnutrition. Scientific research is therefore needed to discover, based on reliable analytical data, richer and locally available nutritional food sources, which could contribute to improve the health of the population.

Cucurbit seeds are largely cultivated in Nigeria and in Cote d'Ivoire, but only on a small scale in Cameroon (Mabaleha et al., 2007). In these countries, the dried decorticated seeds are usually ground into a paste and used to thicken soups, or directly added in vegetable dishes. The Akan people in Cote d'Ivoire also use Cucurbit seed meals during the yam festival (Zoro Bi et al., 2003). In Cameroon Cucurbit seeds are the main foods or ingredients during traditional and public ceremonies in some tribes (Fomekong et al., 2008) such as nguon (Bamoun people), ngodo (Bassa people), birth celebrations (Bamileke people) and traditional marriages in most tribes in Cameroon. In some parts of Cameroon, some of the species are cultivated mostly for their leaves and fruits as vegetables, while the seeds are discarded because they are smaller in size and are very time-consuming to decorticate in great quantities.

Cucurbit (egusi) seeds are also considered as important sources of lipids (42.9 - 57.3\%) (Achu et al., 2005). Some of these seeds are also used for oil extraction (Schippers, 1997). Their oils contain $18.62-20.11 \%$ of saturated fatty acids, $14.90-32.40 \%$ of monounsaturated fatty acids and $35.72-56.84 \%$ of polyunsaturated acids. They have high levels of linoleic acid (49-69\%) but very little linolenic acid (0.1 - 0.2\%) (Fokou et al., 2009; Anwar et al., 2011 and Kim et al., 2012). These seeds have low levels of carbohydrates (7.11-10.01\%) (Achu et al., 2005). They also contain minerals like phosphorus, magnesium, potassium, sodium, iron, zinc, copper, manganese and especially calcium (129.7 - $269.7 \mathrm{mg} / 100 \mathrm{~g}$ ) in abundance (Nkanyiso et al., 2015). These seeds have high antioxidant capacities (especially $C$. sativus) and the ability of their oils to trap the DPPH radical, is similar to that of olive oil (especially L. siceraria oil) (Achu et al., 2016).

Cucurbit seeds also have therapeutic properties (Nmila et al., 2002). In traditional medicine, Cucurbit seed kernels are commonly used in renal disorders such as kidney and bladder stones, painful and burning micturition, ulcers in the urinary tract, suppression of urine, jaundice, chronic fevers, inflammation of the liver and kidney (Ullah $\boldsymbol{e t}$ al., 2015). Other studies have shown that Cucurbit oilseeds are therapeutic foods due to their high contents in $\alpha$ galactosidase, dihydroxytriterpenes, sitosterol, carotenes, triterpenoids and flavonoids (Akihisa et al., 1997). The winter melon (Benincasa hispida) is rich in $\alpha$-tocopherol (31.1-207.6 mg/kg) and $\delta$-tocopherol $(60.4-146.0 \mathrm{mg} / \mathrm{kg})$. It also has high levels of $\beta$-sitosterol (54.62- 60.50\%), campesterol (15.10-18.50\%), stigmasterol (11.00-14.30\%) and $\Delta^{5}$-avenasterol (6.40-8.14\%) (Anwar et al., 2011). The tocopherols have the capacity to prevent the oxidation of unsaturated fatty acids in cell membranes and phytosterols help to prevent chronic diseases (Phillips et al., 2005; Ryan et al., 2007). Other studies have reported that Cucurbit seeds could be used to treat benign prostatic hyperplasia, to reduce blood cholesterol and to decrease the risk of certain types of cancers because of its high $\beta$ sitosterol content (Tsai et al., 2006). In addition, a review of scientific studies from 1966 to 2005 revealed that $\alpha$ tocopherol might reduce the risk of Parkinson's disease (Etminan et al., 2005). Similarly, a positive correlation has been shown between tocopherol intake and prevention of Alzheimer's disease (Li et al., 2012). Cucurbit seeds also contain high levels of dietary fibre, which contribute in weight loss, hence preventing or reducing cardiovascular illnesses and type 2 diabetes (Liu et al., 2003 and Galisteo et al., 2008).

In view of all these nutritional and health benefits of Cucurbit (egusi) seeds, very little data is available on the dietary fibre and vitamin contents of these seeds especially from Cameroon. This study therefore analysed the contents of insoluble, soluble and total dietary fibre and a natural antioxidant (vitamin E) in the seeds of Cucumeropsis mannii, Cucurbita maxima, Cucurbita moschata, Lagenaria siceraria and Cucumis sativus from different agro-ecological zones in Cameroon.

\section{Materials and Methods:- Collection and identification of samples}

The seeds, dried and decorticated under local conditions by the farmers, were collected from three different agroecological zones in Cameroon, from September to November 2014. They comprised 29 samples of 5 species, identified at the National Herbarium in Yaoundé (Table 1). 
Table 1:-Identification and geographical origin of the Cucurbit seeds sampled from different regions of Cameroon

\begin{tabular}{|c|c|c|c|c|}
\hline $\begin{array}{l}\text { Botanical } \\
\text { identification }\end{array}$ & $\begin{array}{l}\text { Identification Code at the } \\
\text { National Herbarium } \\
\text { Cameroon }\end{array}$ & $\begin{array}{l}\text { Agro-ecological } \\
\text { Zone }\end{array}$ & Region & Locality \\
\hline \multirow[t]{2}{*}{$\begin{array}{l}\text { Lagenaria } \\
\text { siceraria (Molina) } \\
\text { Standl. }\end{array}$} & \multirow[t]{2}{*}{$\begin{array}{l}\text { Jacques Felix's collection } \mathrm{n}^{\circ} \text { : } \\
8540 \text { registered under the } \mathrm{n}^{\circ} \text { : } \\
24388 \text { / FRSC. }\end{array}$} & $\begin{array}{l}\text { High Plateaus of the } \\
\text { West }\end{array}$ & North West & $\begin{array}{l}\text { Mankon } \\
\text { Ndop } \\
\text { Wum }\end{array}$ \\
\hline & & $\begin{array}{l}\text { High Plateaus } \\
\text { the West }\end{array}$ & West & $\begin{array}{l}\text { Bafoussam } \\
\text { Dschang } \\
\text { Bamougoum }\end{array}$ \\
\hline \multirow[t]{2}{*}{$\begin{array}{l}\text { Cucurbita } \\
\text { moschata (Lam.) } \\
\text { Poir. }\end{array}$} & \multirow[t]{2}{*}{$\begin{array}{l}\text { Jacques Felix's collection no: } \\
8539 \text { registered under the no: } \\
24387 \text { / FRSC. }\end{array}$} & $\begin{array}{l}\text { High Plateaus of } \\
\text { the West }\end{array}$ & North West & $\begin{array}{l}\text { Mankon } \\
\text { Zhoa } \\
\text { Wum }\end{array}$ \\
\hline & & $\begin{array}{l}\text { High Plateaus of } \\
\text { the West }\end{array}$ & West & $\begin{array}{l}\text { Dschang } \\
\text { Foumbot } \\
\text { Bamougoum } \\
\end{array}$ \\
\hline \multirow[t]{2}{*}{$\begin{array}{l}\text { Cucumeropsis } \\
\text { mannii Naudin }\end{array}$} & \multirow[t]{2}{*}{$\begin{array}{l}\text { Westphal's collection no: } 9389 \\
\text { registered under the no: } 42485 \text { / } \\
\text { NHC. }\end{array}$} & $\begin{array}{l}\text { High Plateaus } \\
\text { the West }\end{array}$ & North West & $\begin{array}{l}\text { Bangolan } \\
\text { Wum } \\
\text { Essimbi }\end{array}$ \\
\hline & & $\begin{array}{l}\text { High Plateaus } \\
\text { the West }\end{array}$ & West & $\begin{array}{l}\text { Baloum } \\
\text { Bamougoum } \\
\text { Galim }\end{array}$ \\
\hline \multirow[t]{2}{*}{$\begin{array}{l}\text { Cucumis sativus } \\
\text { L. }\end{array}$} & \multirow{2}{*}{$\begin{array}{l}\text { Westphal's collection no: } 9062 \\
\text { registered under the no: } 42457 \text { / } \\
\text { HNC. }\end{array}$} & Humid Forest & Centre & $\begin{array}{l}\text { Bafia } \\
\text { Mbalmayo Obala } \\
\end{array}$ \\
\hline & & Swamp Forest & South West & $\begin{array}{l}\text { Buea } \\
\text { Mamfe } \\
\text { Mundemba }\end{array}$ \\
\hline \multirow[t]{2}{*}{$\begin{array}{l}\text { Cucurbita maxima } \\
\text { Duch. }\end{array}$} & \multirow{2}{*}{$\begin{array}{l}\text { Compared to the botanical } \\
\text { collection of Westphal no: } 9564 \\
\text { registered under the no: } 42514 \text { / } \\
\text { NHC. }\end{array}$} & $\begin{array}{l}\text { High Plateaus of } \\
\text { the West }\end{array}$ & West & $\begin{array}{l}\text { Galim } \\
\text { Bangangte } \\
\text { Foumbot }\end{array}$ \\
\hline & & $\begin{array}{l}\text { High Plateaus of } \\
\text { the West }\end{array}$ & North West & $\begin{array}{l}\text { Kom } \\
\text { Bangolan }\end{array}$ \\
\hline
\end{tabular}

FRSC: Forest Research Section of Cameroon, NHC: National Herbarium of Cameroon

\section{Determination of water content}

The water content of the seeds was determined according to the method of AOAC (1980). About $10 \mathrm{~g}$ of seeds were dried in an air-ventilated oven (Mermmert /Beschickung-Loading, Modell 100 - 800) at $105{ }^{\circ} \mathrm{C}$ until constant weight. The water content was expressed in $\mathrm{g} / 100 \mathrm{~g}$ of fresh weight (FW).

\section{Treatment of samples}

The decorticated seeds were dried in an air-ventilated oven (Mermmert /Beschickung-Loading, Modell 100 - 800) at $50{ }^{\circ} \mathrm{C}$ for 48 hours and ground with an electric grinder (Blender B1-500, Sinsung, Singapore). The seed flours were put in air-tight bottles and stored at $4{ }^{\circ} \mathrm{C}$ prior to analyses.

\section{Lipid extraction}

The total lipids of the seeds were extracted at room temperature with the solvent mixture extraction method described by Folch et al. (1957) with slight modifications. Dichloromethane which is more volatile than chloroform was used instead chloroform during the extraction step. $10 \mathrm{~g}$ of oven-dried seed powder were mixed with $50 \mathrm{~mL}$ of dichloromethane/methanol (2/1 v/v) solvent in a $100 \mathrm{~mL}$ beaker. The content was stirred for 20 minutes and filtered through a filter paper (Whatman $\mathrm{N}^{\mathrm{o}} 2$ ). The operation was repeated on the residue. $20 \mathrm{~mL}$ of $0.9 \% \mathrm{NaCl}$ was added to the filtrates. The mixture was poured into a separatory funnel, vigorously stirred and allowed to stand for 24 hours at room temperature for phase separation to take place. The lower phase that was made up of dichloromethane and dissolved lipids was collected into dark bottles and covered with a thin paper for 48 hours at room temperature, in the dark, for the solvent to evaporate. The extracted oil was stored at $4{ }^{\circ} \mathrm{C}$ and later used for the analysis of vitamin 
E. The extraction residues, representing the defatted samples were dried at room temperature (by allowing the traces of solvent to evaporate) for $48 \mathrm{~h}$ and weighed. They were later ground and used for the analysis of dietary fibre.

\section{Analysis of dietary fibre: soluble, insoluble and total dietary fibre}

Dietary fibre was analysed using the enzymatic method described by Prosky et al. (1992): AACC method 32-05, AOAC 985. 29a. The defatted sample was sequentially digested using the Megazyme kits containing three thermostable enzymes: $\alpha$-amylase (Megazyme cat. no. E-BLAAM), protease (Megazyme cat. no. E-BSPRT) and amyloglucosidase (Megazyme cat. no. E-AMGDF). The fibre content was corrected using the blank, residual protein and ash contents as described below.

\section{Enzymatic digestion}

Exactly $1 \mathrm{~g}$ of defatted sample was weighed in duplicate into two $400 \mathrm{~mL}$ beakers and mixed with $50 \mathrm{~mL}$ of $0.08 \mathrm{M}$ phosphate buffer ( $\mathrm{pH}$ 6.0). The mixtures were well homogenized. $50 \mu \mathrm{L}$ of heat-stable $\alpha$-amylase (Megazyme cat. no. E-BLAAM) were added into each beaker. The beakers were covered with aluminium foil and incubated in a water bath at $97{ }^{\circ} \mathrm{C}$ for 35 minutes with stirring every 5 minutes. The mixtures were removed from the water bath, allowed to cool to $60{ }^{\circ} \mathrm{C}$ and the $\mathrm{pH}$ was adjusted to 7.5 by adding $1.5 \mathrm{~mL}$ of $\mathrm{NaOH}, 0.275 \mathrm{~N}$. $100 \mu \mathrm{L}$ of protease (Megazyme cat. no. E-BSPRT) were added. The temperature of the water bath was adjusted to $60{ }^{\circ} \mathrm{C}$ and the beakers incubated at this temperature for 30 minutes with shaking every 5 minutes. After cooling, the pH was adjusted to 4.5 with $5 \mathrm{~mL}$ of $0.325 \mathrm{~N} \mathrm{HCl} .200 \mu \mathrm{L}$ of amyloglucosidase (Megazyme cat. no. E-AMGDF) were then added and the flasks were again incubated at $60{ }^{\circ} \mathrm{C}$ for 30 minutes.

\section{Assay of insoluble fibre}

The mixtures were filtered on previously weighed $\left(\mathrm{P}_{1}, \mathrm{~g}\right)$ sintered glass $\mathrm{N}^{\circ} 1$ and the residues rinsed with two portions of $10 \mathrm{~mL}$ of preheated distilled water at $70{ }^{\circ} \mathrm{C}$. The filtrates, containing the soluble fibre were collected into $250 \mathrm{~mL}$ beakers for the assay of soluble dietary fibre. The residues were washed again two times with $10 \mathrm{~mL}$ ethanol $95 \%$ and $10 \mathrm{~mL}$ acetone, and finally dried in an oven at $105{ }^{\circ} \mathrm{C}$ for 12 hours. The sintered glasses with the residues were then cooled in a desiccator for 1 hour and weighed $\left(\mathrm{P}_{2}, \mathrm{~g}\right)$. The difference in weight gave the mass of the insoluble fibre. One residue was analysed for protein, determined by the Kjeldahl method and the second residue was incinerated for ash content determination (AOAC, 1980). The content of the uncorrected insoluble fibre, reported to $100 \mathrm{~g}$ of defatted sample, was corrected with its protein and ash contents, in order to obtain the insoluble fibre content $(\mathrm{g} / 100 \mathrm{~g})$ of the oven-dried, ground and defatted seeds.

\section{Assay of Soluble fibre}

The soluble fibre contained in the filtrate was precipitated for 1 hour with $320 \mathrm{~mL}$ of hot ethanol $95 \%$. The resulting mixture was filtered through a weighed $\left(\mathrm{P}^{\prime}{ }_{1}, \mathrm{~g}\right)$ sintered glass $\mathrm{N}^{\mathrm{o}} 1$. The residue was washed two times with $10 \mathrm{~mL}$ of distilled water, two times with $15 \mathrm{~mL}$ of $78 \%$ ethanol (v/v), two times with $15 \mathrm{~mL}$ of $95 \%$ ethanol, and two times with $15 \mathrm{~mL}$ of pure acetone. The residue was then dried in an oven at $105{ }^{\circ} \mathrm{C}$ for 12 hours, the glass was cooled in a desiccator for 1 hour and weighed $\left(\mathrm{P}_{2}^{\prime} \mathrm{g}\right)$. The difference in weight gave the mass of the soluble fibre. The residual protein content was determined by the Kjeldahl method in one of the residues. The factor 6.25 was used as conversion factor of nitrogen to protein. The residual ash in the other residue was determined by weighing after incineration at $525{ }^{\circ} \mathrm{C}$ for 5 hours (AOAC, 1980). Protein and ash contents were subtracted from the weight of the dry residue to correct the soluble fibre content.

\section{Calculation of total dietary fibre}

The total dietary fibre was defined as the sum of the soluble fibre and insoluble fibre.

Another flask, the blank containing only enzyme, reagents and solvent, underwent the same procedure as the trials. The insoluble, soluble and total dietary fibre contents were expressed in $\mathrm{g} / 100 \mathrm{~g}$ Edible Portion (EP).

\section{Analysis of vitamin E}

Vitamin E was analysed directly from the lipid extracts using Ultra-High Performance Liquid Chromatography (UHPL) paired with fluorescence detection according to Buttriss and Diplock (1984) with the method described in Awada et al. (2013). Briefly, the separation, detection and quantification of tocopherol isomers was performed with an HPLC apparatus (RS-LC Ultimate 3000, DIONEX) equipped with a fluorescence detector $(\lambda \mathrm{ex}=295 \mathrm{~nm}, \lambda \mathrm{em}=$ $330 \mathrm{~nm}$ ) and fitted with a silica column (Uptisphere strategy SI, L x d: 150x4.6 mm, granulometry: $2.2 \mu \mathrm{m}$, INTERCHIM). 
After injection of the oil samples $\left(40 \mu \mathrm{L}\right.$ ) dissolved in n-hexane at $20 \mathrm{mg} / \mathrm{mL}$ (sample temperature, $10^{\circ} \mathrm{C}$ ), the separation of isomers was achieved in isocratic mode with $\mathrm{n}$-hexane /terbutylmethyl ether $(90 / 10, \mathrm{v} / \mathrm{v})$ at a flow rate of $1.0 \mathrm{~mL} / \mathrm{min}$ and a pressure of $80-90$ bars. The temperature of the column oven was regulated at $30^{\circ} \mathrm{C}$. The identification of the isomers was performed by comparing the peak retention times with that of a standard mixture of $\alpha, \beta, \gamma, \delta$-tocopherols (tocopherol set Calbiochem Cat : 613424-1SET) and $\gamma$,-tocotrienol standard (Cayman Chemical Company, ref: 10008494). All determinations were performed in triplicate. The quantification was made with external calibration curves prepared from a range of calibration solutions made with the same standards. The results were expressed as $\mu \mathrm{g} / \mathrm{gof}$ lipid and $\mu \mathrm{g} / \mathrm{g}$ EP of seed.

\section{Statistical Analyses:-}

Analysis of variance, ANOVA was done (at a probability level of 5\% with the software STATGRAPHICS plus 5.0), to evaluate the interaction between the species and their ecological region of cultivation and between the various species of seeds without considering the region of cultivation. Where the ANOVA test indicated significant differences, the Least Significance Difference, LSD test (at the same probability level) was used to locate these differences.

\section{Results and Discussion:- Water content}

The water contents of the Cucurbit oilseeds are presented on Table 2. They ranged from $3.94 \pm 0.40$ (C. maxima) to $5.69 \pm 0.73 \mathrm{~g} / 100 \mathrm{~g}$ fresh weight, FW (C. sativus) and did not depend on the region of cultivation ( $\mathrm{p}>0.05)$ but on the specie. There was no significant difference between the water contents of $L$. siceraria $(4.85 \pm 0.17)$, C. moschata $(5.30 \pm 0.32)$ and $C$. mannii $(5.32 \pm 0.39)$. These values were similar to those found for Cucurbit seeds from Niger, Luffa aegyptiaca (5.25 \pm 0.35$)$ and Luffa cylindrica (5.05 \pm 0.34$)$ (Sadou et al., 2005) and C. sativus (5.65 \pm 0.97$)$ from Cameroon. They were however lower than water contents from previous studies on C. moschata (8.21 \pm 1.47$)$, C. maxima (6.94 \pm 1.92$)$, C. mannii (6.49 \pm 0.62$)$ and $L$. siceraria $(6.09 \pm 0.20)$ (Achu et al., 2005). These different values especially from Cameroon seeds may be due to the state of maturity of the seeds, the season of harvest, the conditions and duration of drying and storage of the seeds by the farmers before they were bought and taken to the laboratory for analyses. These values are also similar to those obtained by Kershaw and Hackett (1987) for other edible oilseeds such as cottonseeds $(6.46 \%)$, peanuts $(4.58 \%)$, palm kernel $(5.31 \%)$, sesame $(4.60 \%)$ and sunflower seeds $(6.58 \%)$. The seeds were bought already dried locally by the farmers. The water content in these seeds was generally lower than $6 \%$. The low water content in these Cucurbit seeds allows them to be free from microbial growth, hence enabling preservation for a long time (closed to a year and even more) even at room temperature, if they are well dried under local conditions.

\section{Insoluble, soluble and total dietary fibre contents}

The dietary fibre contents of the seeds are shown on Table 2.

The insoluble dietary fibre (IDF) content varied from $15.70 \pm 1.61$ (C. sativus) to $19.21 \pm 1.29 \mathrm{~g} / 100 \mathrm{~g} \mathrm{EP}$ (C. mannii). It did not depend on the region of cultivation ( $\mathrm{p}>0.05)$ but on the specie. $C$. mannii $(19.21 \pm 1.29)$ and $L$. siceraria $(18.53 \pm 1.67)$ had similar IDF contents, significantly higher than the rest of the seeds. The seeds analysed in the present study had lower IDF content than bambara groundnuts $(20.68 \pm 0.6)$, black beans $(21.61 \pm 0.7)$, white beans $(21.69 \pm 0.4)$ and peas $(22.21 \pm 09 \mathrm{~g} / 100 \mathrm{~g}$ EP) (Tanya et al., 1997). Insoluble fibre is insoluble in water. It is made up of hemicellulose, cellulose and lignin (Howarth et al., 2001). It increases the duration of chyme in the stomach, increases satiety and eases faecal excretion by improving hydration (Chaplin, 2004). The insoluble dietary fibre made up the bulk of dietary fibre in these seeds ( $74-81 \%$ of the total dietary fibre). These seeds therefore have potential for easing faecal excretion and preventing constipation (Pereira et al., 2001).

The soluble dietary fibre (SDF) levels varied from $4.35 \pm 1.18$ (C. maxima) to $6.60 \pm 0.86 \mathrm{~g} / 100 \mathrm{~g}$ EP ( $L$. siceraria). They were independent of the region of cultivation ( $p>0.05)$ but significantly depended on the Cucurbit specie $(\mathrm{p}<0.05)$. The SDF content for $L$. siceraria $(6.60 \pm 0.86)$ was similar to that of $C$. mannii $(5.87 \pm 0.53)$, but higher than those of $C$. sativus $(4.49 \pm 0.45)$ and $C$. maxima $(4.35 \pm 1.18 \mathrm{~g} / 100 \mathrm{~g}$ EP) (LSD test, $\mathrm{p}<0.05)$. The content for $C$. moschata seeds $(5.32 \pm 0.62 \mathrm{~g} / 100 \mathrm{~g} \mathrm{EP})$ was not significantly different from those of the other species. The content of SDF makes up $19-26 \%$ of the total dietary fibre in these Cucurbit seeds. These seeds are richer in SDF than black beans $(3.85 \pm 0.3)$, bambara groundnut $(3.15 \pm 0.4)$ and peas $(2.44 \pm 0.1 \mathrm{~g} / 100 \mathrm{~g} \mathrm{EP})$ (Tanya et al., 1997). Soluble fibre are components of fibre that easily dissolve in water. They are made up of pectin, 
gums and mucilage (Hanai $\boldsymbol{e t ~ a l . , ~ 1 9 9 7 ) . ~ S o l u b l e ~ f i b r e ~ c a n ~ d e c r e a s e ~ l o w - d e n s i t y ~ l i p o p r o t e i n ~ ( L D L ) ~ c h o l e s t e r o l ~ l e v e l s ~}$ and contribute to regulate blood glucose and insulin levels (Ripsin et al., 1992; Brown et al., 1999).

The total dietary fibre (TDF) levels ranged between $20.19 \pm 1.81$ (C. sativus) and $25.13 \pm 1.68 \mathrm{~g} / 100 \mathrm{~g}$ EP ( $L$. siceraria). The TDF content of C. moschata $(21.30 \pm 2.34)$ was similar to those of $C$. sativus $(20.19 \pm 1.81)$ and $C$. maxima (22.75 \pm 0.24 ), while that of $C$. mannii $(25.08 \pm 1.31$ ) was similar (LSD test, $\mathrm{p}>0.05)$ to that of $L$. siceraria $(25.13 \pm 1.68)$ with higher values. The variation in dietary fibre levels of these seeds could be due to their genetic diversity and the state of maturity of the seeds. The values of $L$. siceraria and $C$. mannii were closer to those of black beans (25.46) and peas (24.65) whereas those of the other species were similar to that of bambara groundnut (23.82 g /100 g EP) (Tanya et al., 1997). Following the recommendations of the American Diabetes Association, $100 \mathrm{~g}$ of these Cucurbit oilseeds $(15.70-19.21 \mathrm{~g} / 100 \mathrm{~g} \mathrm{EP})$ therefore contain the required insoluble dietary fibre $(\mathbf{1 6 g} / \mathbf{d a y})$ whereas, their soluble fibre is lower than $8 \mathrm{~g} /$ day. The recommended allowances for dietary fibre from 1 8 years is $19-25 \mathrm{~g} /$ day, from $9-13$ years is $26-38 \mathrm{~g} / \mathrm{day}$, from $19-50$ years is $25-38 \mathrm{~g} /$ day and more than 50 years is $21-30 \mathrm{~g} / \mathrm{day}$ in women and men of the same age respectively. (Institute of Medicine, 2005). 100g of these Cucurbit seeds contained $20.19-25.13 \mathrm{~g}$ EP of TDF. This means that consumption of $100 \mathrm{~g}$ of these seeds especially L. siceraria, can cover the dietary fibre needs per day for children of $1-8$ years old and women, and also cover about $70 \%$ of fibre needs in men.

The high contents of dietary fibre in these seeds are mostly due to the high levels of insoluble dietary fibre, IDF. The similarity of the values of insoluble and soluble dietary fibre in C. mannii, C. maxima and C. moschata could be due to their vegetal matrix comparable to those of $L$. siceraria and $C$. sativus. These Cucurbit seeds would therefore contain more cellulose, hemicellulose and lignin (IDF fraction) than pectin, gums and mucilage, which are components of soluble fibre. IDF could help facilitate digestion and improve the functioning of the digestive system. The SDF (pectin, gum and mucilage), in these seeds present in lower levels than IDF could also be useful in regulating LDL cholesterol, blood glucose and insulin levels (Meyer et al., 2000).

Table 2:-Water and dietary fibre (Insoluble, IDF; Soluble, SDF and Total, TDF) contents of Cucurbit oilseeds from Cameroon

\begin{tabular}{|c|c|c|c|c|c|c|}
\hline Species & Region & Locality & $\begin{array}{l}\text { Water } \\
(\mathrm{g} / 100 \mathrm{~g} \mathrm{FW})\end{array}$ & $\begin{array}{c}\text { IDF } \\
\text { (g /100g EP) }\end{array}$ & $\begin{array}{l}\text { SDF } \\
(\mathrm{g} / 100 \mathrm{~g} \text { EP) }\end{array}$ & $\begin{array}{l}\text { TDF } \\
\text { (g/100g EP) }\end{array}$ \\
\hline \multirow{7}{*}{$\begin{array}{l}\text { L. } \\
\text { siceraria }\end{array}$} & \multirow{4}{*}{$\begin{array}{l}\text { West } \\
\text { North }\end{array}$} & Mankon & 4.66 & 19.82 & 5.90 & 25.73 \\
\hline & & Ndop & 5.01 & 18.61 & 8.16 & 26.78 \\
\hline & & \multirow[t]{2}{*}{ Wum } & 4.63 & 15.24 & 6.70 & 21.94 \\
\hline & & & $4.77 \pm 0.21$ & $17.89 \pm 2.37$ & $6.92 \pm 1.14$ & $24.82 \pm 2.54$ \\
\hline & \multirow{5}{*}{ West } & Bafoussam & 4.95 & 19.35 & 5.75 & 25.10 \\
\hline & & Dschang & 5.02 & 19.40 & 6.64 & 26.04 \\
\hline & & \multirow[t]{2}{*}{ Bamougoum } & 4.84 & 18.73 & 6.45 & 25.18 \\
\hline & & & $4.94 \pm 0.10$ & $19.16 \pm 0.38$ & $6.28 \pm 0.47$ & $25.44 \pm 0.52$ \\
\hline & & Mean & $4.85 \pm 0.17^{\mathrm{a}}$ & $18.53 \pm 1.67^{b}$ & $6.60 \pm 0.86^{c}$ & $25.13 \pm 1.68^{\mathrm{c}}$ \\
\hline \multirow{9}{*}{$\begin{array}{l}\text { C. } \\
\text { moschata }\end{array}$} & \multirow{4}{*}{$\begin{array}{l}\text { North } \\
\text { West }\end{array}$} & Mankon & 4.73 & 11.17 & 6.29 & 17.45 \\
\hline & & Zhoa & 5.55 & 15.05 & 5.19 & 20.23 \\
\hline & & Wum & 5.21 & 18.65 & 5.67 & 24.32 \\
\hline & & & $5.16 \pm 0.41$ & $14.96 \pm 3.64$ & $5.71 \pm 0,55$ & $20.67 \pm 3.46$ \\
\hline & & Dschang & 5.36 & 16.73 & 6.00 & 22.73 \\
\hline & & Foumbot & 5.34 & 15.83 & 5.41 & 21.24 \\
\hline & West & Bamougoum & 5.62 & 17.27 & 4.57 & 21.84 \\
\hline & & & $5.44 \pm 0.16$ & $16.61 \pm 0.73$ & $5.63 \pm 0.72$ & $21.94 \pm 0.75$ \\
\hline & & Mean & $5.30 \pm 0.32^{b c}$ & $15.78 \pm 2.58^{a}$ & $5.32 \pm 0.61^{a b c}$ & $21.30 \pm 2.34^{a}$ \\
\hline & & Bangolan & 5.16 & 20.10 & 5.43 & 25.53 \\
\hline & North & Wum & 5.44 & 19.98 & 6.26 & 26.24 \\
\hline & West & Essimbi & 5.18 & 18.63 & 5.33 & 23.96 \\
\hline & & & $5.26 \pm 0.15$ & $19.57 \pm 0.81$ & $5.67 \pm 0.51$ & $25.24 \pm 1.17$ \\
\hline C. mannii & & Baloum & 4.91 & 19.83 & 6.53 & 26.36 \\
\hline & West & Bamougoum & 5.20 & 19.89 & 5.44 & 25.33 \\
\hline
\end{tabular}




\begin{tabular}{|c|c|c|c|c|c|c|}
\hline & & \multirow[t]{2}{*}{ Galim } & 6.05 & 16.82 & 6.25 & 23.06 \\
\hline & & & $5.38 \pm 0.59$ & $18.84 \pm 1.76$ & $6.07 \pm 0.57$ & $24.92 \pm 1.69$ \\
\hline & & Mean & $5.32 \pm 0.39^{\text {bc }}$ & $19.21 \pm 1.29^{b}$ & $5.87 \pm 0.53^{\mathrm{c}}$ & $25.08 \pm 1.31^{c}$ \\
\hline \multirow{9}{*}{ C. sativus } & \multirow[t]{3}{*}{ Centre } & Bafia & 5.36 & 17.90 & 4.70 & 22.61 \\
\hline & & Mbalmayo & 5.70 & 13.02 & 4.29 & 17.30 \\
\hline & & Obala & 4.86 & 15.43 & 3.75 & 19.18 \\
\hline & & & $5.31 \pm 0.42$ & $15.45 \pm 2.44$ & $4.25 \pm 0.48$ & $19.70 \pm 2.69$ \\
\hline & \multirow{5}{*}{$\begin{array}{l}\text { South } \\
\text { West }\end{array}$} & Buea & 5.92 & 15.93 & 4.47 & 20.39 \\
\hline & & Mamfe & 6.98 & 16.58 & 4.70 & 21.27 \\
\hline & & Mundemba & 5.28 & 15.33 & 5.05 & 20.37 \\
\hline & & & $6.06 \pm 0.86$ & $15.94 \pm 0.63$ & $4.74 \pm 0.29$ & $20.68 \pm 0.52$ \\
\hline & & Mean & $5.69 \pm 0.73^{\mathrm{c}}$ & $15.70 \pm 1.61^{\mathrm{a}}$ & $4.49 \pm 0.45^{\mathrm{a}}$ & $20.19 \pm 1.81^{a}$ \\
\hline \multirow{8}{*}{$\begin{array}{l}C . \\
\text { maxima }\end{array}$} & \multirow[t]{4}{*}{ West } & Galim & 4.15 & 17.52 & 5.38 & 22.89 \\
\hline & & Bangangte & 3.73 & 18.70 & 4.13 & 22.83 \\
\hline & & Foumbot & 4.33 & 17.58 & 5.02 & 22.61 \\
\hline & & & $4.07 \pm 0.31$ & $17.93 \pm 0.66$ & $4.84 \pm 0.64$ & $22.77 \pm 0.15$ \\
\hline & \multirow{4}{*}{$\begin{array}{l}\text { North } \\
\text { West }\end{array}$} & \multirow{3}{*}{$\begin{array}{l}\text { Kom } \\
\text { Bangolan }\end{array}$} & 3.34 & 17.59 & 4.82 & 22.42 \\
\hline & & & 4.16 & 20.60 & 2.42 & 23.02 \\
\hline & & & $3.75 \pm 0.58$ & $19.09 \pm 2.12$ & $3.62 \pm 1.70$ & $22.72 \pm 0.43$ \\
\hline & & Mean & $3.94 \pm 0.40^{b}$ & $18.40 \pm 1.32^{b}$ & $4.35 \pm 1.18^{\mathrm{a}}$ & $22.75 \pm 0.24^{\text {ab }}$ \\
\hline
\end{tabular}

$\mathrm{EP}=$ Edible portion of seeds, FW $=$ Fresh Weight

\section{Anova:}

There was no significant difference ( $p>0.05 ; \mathrm{n}=3 \times 2$ ) between the mean values of the parameters studied (water, IDF, $\mathrm{SDF}, \mathrm{TDF}$ ) for the same specie from the two regions of cultivation.

In the same column, mean values with different letter superscripts in the same column indicate significantdifferences between given Cucurbit species $(\mathrm{p}<0.05 ; \mathrm{n}=6)$.

\section{Vitamin E content}

Tocopherols $(\alpha, \beta, \gamma$ and $\delta$ - tocopherol) and tocotrienols were analysed in the oils extracted from the seeds. The results are shown on Table 3. These results showed the absence of all forms of tocotrienols. $\beta$-tocopherol was also absent while the other three forms of tocopherols were present in all the samples. The tocopherol contents did not depend on the region of origin $(p>0.05)$ but on the specie $(p<0.05)$.

Alpha ( $\boldsymbol{\alpha}$ )-tocopherol was absent in $C$. mannii oils. It ranged from $3.87 \pm 3.14(1.42 \pm 1.16 \mu \mathrm{g} / \mathrm{g}$ EP of seed) $(C$. maxima) to $9.84 \pm 6.00 \mu \mathrm{g} / \mathrm{g}$ of lipid) $(3.12 \pm 1.96 \mu \mathrm{g} / \mathrm{g}$ EP of seed) (L. siceraria). $\alpha$-tocopherol makes up 0.9 $\mathbf{5 . 8 \%}$ of the total tocopherols in these oils. The value for $L$. siceraria was significantly higher than $(\mathrm{p}<0.05)$ those of the other species. These values were higher than those of Luffa (Cucurbit seeds from Niger) $(4.20 \pm 2.38 \mu \mathrm{g} / \mathrm{g}$ of lipid) (Sadou et al., 2005) except C. maxima and C. sativus (4.21 $\pm 4.41 \mu \mathrm{g} / \mathrm{g}$ of lipid). The $\alpha$-tocopherol levels of the oils in the seeds studied were much lower than those of C. maxima $(27.1-75.1 \mu \mathrm{g} / \mathrm{g}$ of lipid) from NewZealand and Africa, cultivated in an experimental farm in Iowa, United States of America (Stevenson et al., 2007), C. maxima (128 $\pm 14.42 \mu \mathrm{g} / \mathrm{g}$ of lipid) from Tunisia (Rezig et al., 2012) and C. maxima (203 - $353 \mu \mathrm{g} / \mathrm{g}$ of lipid) from Serbia (Naziri et al., 2016). This large difference in values may be due to the differences in the areas and methods of cultivation of the seeds, treatment of the seeds after harvest and the methods of extraction of the oils for vitamin $\mathrm{E}$ analysis. $\alpha$ - tocopherol decreases lipid peroxidation in food oils during processing and storage. It Inhibits protein kinase $\mathrm{C}$ - mediated monocyte superoxide production, smooth muscle cell proliferation, platelet aggregation and adhesion. Alpha tocopherol modulates inflammatory response by inhibiting 5-lipoxygenase, which in turn decreases monocyte IL-1 $\beta$ release (Mathur et al., 2015).

The oils contained mostly gamma $(\gamma)$-tocopherol, which varied from $87.12 \pm 39.42(39.34 \pm 12.17 \mu \mathrm{g} / \mathrm{g}$ EP of seed) (C. moschata) to $644.86 \pm 130.50 \mu \mathrm{g} / \mathrm{g}$ of lipid $(208.61 \pm 49.09 \mu \mathrm{g} / \mathrm{g}$ EP of seed) (L. siceraria). The high value in $L$. siceraria was followed by that of C. sativus (453.45 $\pm 61.79 \mu \mathrm{g} / \mathrm{g}$ of lipid) (190.12 $\pm 30.56 \mu \mathrm{g} / \mathrm{g}$ EP of seed) which were significantly higher $(\mathrm{p}<0.05)$ than those of $C$. mannii $(363.33 \pm 111.60 \mu \mathrm{g} / \mathrm{g}$ of lipid $)(79.44 \pm$ 
$19.15 \mu \mathrm{g} / \mathrm{g}$ EP of seed) and C. maxima $(206.28 \pm 136.17 \mu \mathrm{g} / \mathrm{g}$ of lipid $)(76.21 \pm 43.30 \mu \mathrm{g} / \mathrm{g}$ EP of seed). $\gamma$ tocopherol makes up $94-99 \%$ of the total tocopherols in these oils. C. moschata and C. maxima, which had lower levels of $\gamma$-tocopherol, were however richer in this compound than those of pumpkin cultivars from New-Zealand and Africa, cultivated in an experimental farm in Iowa, United States of America such as chacha (74.9), hyvita (77.1) and sweet mama (75.8 $\mu \mathrm{g} / \mathrm{g}$ of lipid), while the value in L. siceraria was higher than that of big max (492.8 $\mu \mathrm{g} / \mathrm{g}$ of lipid) (Stevenson et al., 2007) and Luffa (472.18 $\pm 186.70 \mu \mathrm{g} / \mathrm{g}$ of lipid) from Niger (Sadou et al., 2005). The $\gamma$-tocopherol content of $C$. maxima was also higher than that of this specie from Tunisia (113.66 $\pm 1.52 \mu \mathrm{g} / \mathrm{g}$ of lipid (Rezig et al., 2012). C. mannii oil (363.33) showed similar values to that of other edible oils such as groundnut oil ( $360 \mu \mathrm{g} / \mathrm{g}$ of lipid), while all the samples studied contained lower $\gamma$-tocopherol levels than soybean oil (700 $\mu \mathrm{g} / \mathrm{g}$ of lipid) (Luciani et al., 2001). The content of L. siceraria was similar to that of C. maxima (647 - 775 $\mu \mathrm{g} / \mathrm{g}$ of lipid) from Serbia (Naziri et al., 2016). $\gamma$-tocopherol has most of the effects of $\alpha$-tocopherol and is more potent. It removes peroxynitrite-derived reactive nitrogen species. It traps electrophilic nitrogen oxide in cell membranes during inflammation via formation of 5-nitro- $\gamma$-tocopherol. It inhibits smooth muscle cell proliferation, decreases platelet aggregation and delays intra-arterial thrombus formation (Mathur et al., 2015).

Delta (ס)-tocopherol content varied from $0.23 \pm 0.32(0.12 \pm 0.22 \mu \mathrm{g} / \mathrm{g}$ EP of seed) (C. moschata) to $8.52 \pm 1.64$ $\mu \mathrm{g} / \mathrm{g}$ of lipid (3.53 $\pm 0.44 \mu \mathrm{g} / \mathrm{g}$ EP of seed) (C. sativus). The value for $C$. sativus was significantly higher than ( $\mathrm{p}<$ 0.05) those of the other species. $\delta$-tocopherol makes up $\mathbf{0 . 2}-\mathbf{2 . 4} \%$ of the total tocopherols in these oils. These values were lower than those of pumpkin cultivars (35.3 - $1109.7 \mu \mathrm{g} / \mathrm{g}$ of lipid) from New-Zealand and Africa, cultivated in an experimental farm in Iowa, United States of America (Stevenson et al., 2007) and C. maxima from Tunisia (177 $\pm 14.17 \mu \mathrm{g} / \mathrm{g}$ of lipid) (Rezig et al., 2012). $\delta$-tocopherol has potent anti-inflammatory and antioxidant properties by inhibiting cyclooxygenase and 5-lipoxygenase activities. Like other tocopherols, $\delta$-tocopherol contributes to inhibit smooth muscle cell proliferation (Mathur et al., 2015).

The total tocopherol levels ranged from $92.72 \pm 42.19(61.34 \pm 51.16 \mu \mathrm{g} / \mathrm{g}$ EP of seed) (C. moschata) to 662.03 $\pm 134.33 \mu \mathrm{g} / \mathrm{g}$ of lipid $(214.17 \pm 50.47 \mu \mathrm{g} / \mathrm{g}$ EP of seed) (L. siceraria). The high value of $L$. siceraria was followed by that of $C$. sativus $(466.18 \pm 66.88 \mu \mathrm{g} / \mathrm{g}$ of lipid) $(195.30 \pm 31.28 \mu \mathrm{g} / \mathrm{g}$ EP of seed) which were significantly higher than those of the other seeds. The tocopherol content of the lipids from C. maxima $(215.38 \pm 142.72)$ was lower than that of this specie from Tunisia (418.66 $\pm 33.36 \mu \mathrm{g} / \mathrm{g}$ of lipid) (Rezig et al., 2012). Apart from L. siceraria, the tocopherol values of the sample in this study were lower than those of C. maxima seeds (589.4 - 1234.2 $\mu \mathrm{g} / \mathrm{g}$ of lipid) from New-Zealand and Africa, cultivated in an experimental farm in Iowa, United States of America (Stevenson et al., 2007).

Generally, the results of this study showed low levels of $\delta$-tocopherol $(0.2-2.4 \%)$ followed by $\alpha$-tocopherol $(0.9$ $5.8 \%)$ and high levels of $\gamma$-tocopherol (94-99\%). $\alpha$ - tocopherol was absent in C. mannii. These Cucurbit seed oils had good vitamin E levels (total tocopherols) $(92.72-662.03 \mu \mathrm{g} / \mathrm{g}$ of lipid) $(79.59-214.17 \mu \mathrm{g} / \mathrm{g}$ of seed), with $L$. siceraria having the highest levels. The recommended allowances for vitamin $\mathrm{E}$ (as alpha tocopherol equivalence) from $1-13$ years is $6-11 \mathrm{mg} /$ day, above 14 years is $15 \mathrm{mg} /$ day and in pregnancy and lactation is $15-19 \mathrm{mg} / \mathrm{day}$ (Institute of Medicine, 2000). $100 \mathrm{~g}$ of these Cucurbit seeds contained $7.9-21.4 \mathrm{mg}$ of vitamin E. This means that consumption of $100 \mathrm{~g}$ of these seeds especially L. siceraria, can cover the vitamin E needs per day for all age groups. Among the different forms of tocopherol, $\alpha$ - tocopherol is the most biologically active form, while $\gamma$ tocopherol is the most abundant form in foods of plant origin. Vitamin $\mathrm{E}$ is a natural antioxidant (Jordan and Pattison, 1996). $\alpha$-tocopherol and $\gamma$-tocopherol are the most widespread forms in nature. Although $\alpha$-tocopherol is the natural form that presents most vitamin or biological activities, $\gamma$-tocopherol has $10-30 \%$ and $\delta$-tocopherol has $1 \%$ of $\alpha$-tocopherol activity (Tafazoli $\boldsymbol{e t}$ al., 2005). These seeds therefore have antioxidant properties. Their oils could have potential for preventing oxidative stress, tiredness and ageing of cells (Martin, 2001), hence could play a beneficial role in preventing degenerative pathologies such as cardiovascular illnesses, ocular and neurodegenerative pathologies. They can also regulate some gene expressions like those involved in endogenous cholesterol synthesis (Landrier et al., 2010). In addition, tocopherols are among the most important lipid-soluble antioxidants in food as well as in human and animal tissues. Vitamin $\mathrm{E}$ is a potent chain-breaking antioxidant that inhibits the production of reactive oxygen species during lipid oxidation. Alpha tocopherols mainly inhibit the production of new free radicals while $\gamma$-tocopherol traps and neutralises the existing free radicals. This helps prevent chronic diseases associated with reactive oxygen specie molecules such as cancer (Rizvi et al., 2014). Potential health benefits of tocols include prevention of certain types of cancer, heart disease, and other chronic ailments (Shahidi and Camargo, 2016). Technologically, the tocopherol-rich oils may be mixed with some polyunsaturated fatty acids-rich oils to protect 
them against oxidation (Shahidi and Zhong, 2010). During hot treatment of palm oil for example, the addition of tocopherol as antioxidant increased its stability by preventing free fatty acids from heat oxidation (Supriyono et al., 2016). It assures the stability of colour and structure and improves the taste and odour of food (Bourgeois, 2003). In the Cosmetic industry, the tocopherol compounds are used as antioxidant, light stabilizer, hair and skin conditioning and emulsifying agents (Gottschalck and Breslawec, 2012).

Table 3:-Vitamin E (tocopherol) contents of Cucurbit oils ( $\mu \mathrm{g} / \mathrm{g}$ of lipid)

\begin{tabular}{|c|c|c|c|c|c|c|c|}
\hline \multirow[t]{2}{*}{ Species } & \multirow[t]{2}{*}{ Regions } & \multirow[t]{2}{*}{ Localities } & \multicolumn{5}{|c|}{ Tocopherols } \\
\hline & & & $\alpha$ & $\beta$ & 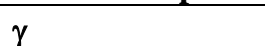 & $\delta$ & Total \\
\hline \multirow{9}{*}{$\begin{array}{l}\text { L. } \\
\text { siceraria }\end{array}$} & \multirow{4}{*}{$\begin{array}{l}\text { North } \\
\text { West }\end{array}$} & Mankon & 15.07 & nd & 737.90 & 6.99 & 759.96 \\
\hline & & Ndop & nd & nd & 546.69 & 5.64 & 552.33 \\
\hline & & Wum & 14.92 & nd & 829.33 & 9.26 & 853.52 \\
\hline & & & $10.00 \pm 8.66^{*}$ & & $704.64 \pm 144.20 *$ & $\begin{array}{ll}7.30 & \pm \\
1.83 & \end{array}$ & $721.93 \pm 154.15 *$ \\
\hline & \multirow[t]{5}{*}{ West } & Bafoussam & 13.62 & nd & 465.98 & 6.11 & 485.71 \\
\hline & & Dschang & 5.90 & nd & 624.09 & 9.75 & 639.74 \\
\hline & & \multirow[t]{2}{*}{ Bamougoum } & 9.52 & nd & 665.17 & 6.22 & 680.91 \\
\hline & & & $9.68 \pm 3.87 *$ & & $\begin{array}{c}\mathbf{5 8 5 . 0 8} \\
\pm 105.17 *\end{array}$ & $\begin{array}{ll}7.36 & \pm \\
2.07 * & \end{array}$ & $602.12 \pm 102.89 *$ \\
\hline & & Mean & $9.84 \pm 6.00^{a}$ & & $644.86 \pm 130.50^{a}$ & $7.33 \pm 1.75^{\mathrm{a}}$ & $\begin{array}{l}662.03 \\
\pm 134.33^{\mathrm{a}}\end{array}$ \\
\hline \multirow{8}{*}{$\begin{array}{l}\text { C. } \\
\text { moschata }\end{array}$} & \multirow{3}{*}{$\begin{array}{l}\text { North } \\
\text { West }\end{array}$} & Mankon & 8.70 & nd & 108.29 & nd & 116.99 \\
\hline & & Wum & 4.10 & nd & 123.64 & 0.58 & 128.32 \\
\hline & & & $6.40 \pm 3.26^{*}$ & & $115.96 \pm 10.86^{*}$ & $\begin{array}{l}0.29 \\
0.41 *\end{array}$ & $122.65 \pm 8.01 *$ \\
\hline & \multirow[t]{5}{*}{ West } & Dschang & 9.26 & nd & 114.46 & 0.57 & 124.29 \\
\hline & & Foumbot & 3.06 & nd & 50.63 & nd & 53.69 \\
\hline & & Bamougoum & 1.75 & nd & 38.56 & nd & 40.31 \\
\hline & & & $4.69 \pm 4.01 *$ & & $67.88 \pm 40.78^{*}$ & $\begin{array}{ll}0.19 & \pm \\
0.33^{*} & \\
\end{array}$ & $72.76 \pm 45.12 *$ \\
\hline & & Mean & $5.37 \pm 3.40^{b}$ & & $87.12 \pm 39.42^{b}$ & $0.23 \pm 0.32^{b}$ & $92.72 \pm 42.19^{b}$ \\
\hline \multirow{9}{*}{$\begin{array}{l}\text { C. } \\
\text { mannii }\end{array}$} & \multirow{4}{*}{$\begin{array}{l}\text { North } \\
\text { West }\end{array}$} & Bangolan & nd & nd & 241.29 & 1.38 & 242.67 \\
\hline & & Wum & nd & nd & 349.49 & 4.11 & 353.60 \\
\hline & & Essimbi & nd & nd & 431.30 & 3.88 & 435.18 \\
\hline & & & & & $340.70 \pm 95.31 *$ & $\begin{array}{l}3.12 \\
1.52 *\end{array}$ & $343.82 \pm 96.63 *$ \\
\hline & \multirow{5}{*}{ West } & Baloum & nd & nd & 239.30 & 1.81 & 241.11 \\
\hline & & Bamougoum & nd & nd & 525.46 & 2.90 & 528.35 \\
\hline & & Galim & nd & nd & 393.14 & 2.13 & 395.27 \\
\hline & & & & & $385.97 \pm 143.21 *$ & $\begin{array}{ll}2.28 & \pm \\
0.56 * & \end{array}$ & 388.25 $\pm 143.75 *$ \\
\hline & & Mean & & & $363.33 \pm 111.60^{c}$ & $2.70 \pm 1.12^{c}$ & $\begin{array}{l}366.03 \\
\pm 112.21^{c}\end{array}$ \\
\hline \multirow{8}{*}{$\begin{array}{l}\text { C. } \\
\text { sativus }\end{array}$} & \multirow{4}{*}{ Centre } & Bafia & 8.06 & nd & 512.55 & 9.36 & 529.97 \\
\hline & & Mbalmayo & 1.32 & nd & 360.91 & 6.39 & 368.63 \\
\hline & & Obala & 0.96 & nd & 401.42 & 6.86 & 409.24 \\
\hline & & & $3.45 \pm 3.10 *$ & & $\begin{array}{r}424.96 \\
+78.51 *\end{array}$ & $7.54 \pm 1.6^{*}$ & $435.95 \pm 83.92 *$ \\
\hline & \multirow{4}{*}{$\begin{array}{l}\text { South } \\
\text { West }\end{array}$} & Buea & 1.21 & nd & 458.38 & 8.42 & 468.01 \\
\hline & & Mamfé & 2.36 & nd & 470.71 & 9.41 & 482.47 \\
\hline & & \multirow[t]{2}{*}{ Mundemba } & 11.37 & nd & 516.72 & 10.68 & 538.76 \\
\hline & & & $4.98 \pm 5.56^{*}$ & & $\begin{array}{l}481.93 \\
30.75^{*}\end{array}$ & $\begin{array}{l}9.50 \\
1.13 *\end{array}$ & $496.42 \pm 37.38 *$ \\
\hline
\end{tabular}




\begin{tabular}{|c|c|c|c|c|c|c|c|}
\hline & & Mean & $4.21 \pm 4.41 b$ & & $453.45 \pm 61.79^{c}$ & $\begin{array}{cc}8.52 & \pm \\
1.64^{\mathrm{a}} & \end{array}$ & $466.18 \pm 66.88^{c}$ \\
\hline \multirow{7}{*}{$\begin{array}{l}\text { C. } \\
\text { maxima }\end{array}$} & \multirow{4}{*}{ West } & Galim & 5.98 & nd & 280.51 & 7.75 & 294.24 \\
\hline & & Bangangté & 6.58 & nd & 320.81 & 7.76 & 335.15 \\
\hline & & Foumbot & 2.93 & nd & 154.84 & 3.44 & 161.20 \\
\hline & & & $5.16 \pm 1.96$ & & $252.05 \pm 86.57 *$ & $\begin{array}{ll}6.32 & \pm 2.49 \\
* & \\
\end{array}$ & $263.53 \pm 90.95^{*}$ \\
\hline & \multirow{3}{*}{$\begin{array}{l}\text { North } \\
\text { West }\end{array}$} & Kom & nd & nd & 68.95 & 1.98 & 70.93 \\
\hline & & & & & $68.95 *$ & $1.98 *$ & 70.93* \\
\hline & & Mean & $3.87 \pm 3.14^{b}$ & & $206.28 \pm 136.17^{d}$ & $5.23 \pm 3.48^{\mathrm{a}}$ & $215.38 \pm 142.72^{d}$ \\
\hline
\end{tabular}

$*=$ no significant difference between the parameters analysed for the same specie from different regions. Detection limit: $1 \mathrm{ng} / \mathrm{g}$; quantification: $10 \mathrm{ng} / \mathrm{g}$

Means with different letter superscripts in the same column indicate a significant difference $(\mathrm{p}<0.05)$ between the parameters analysed for the various species of seeds.

$\alpha=$ Alpha; $\beta=$ Beta $\gamma=$ Gamma; $\delta=$ Delta $; \mathrm{EP}=$ Edible portion, nd $=$ not detected

\section{Conclusion:-}

This study, which was aimed at determining the levels of dietary fibre and vitamin $\mathrm{E}$ in Cucurbit seeds from different regions in Cameroon, revealed that the levels of these parameters varied according to the specie, and not according to the region of cultivation of the seeds. The seeds were rich in dietary fibre especially insoluble dietary fibre. This could help facilitate digestion, improve the functioning of the digestive system. The vitamin $\mathrm{E}$ composition showed that the seeds had high levels of vitamin E (tocopherols), especially L. siceraria. There was the absence of $\gamma$-tocotrienol and $\beta$-tocopherol in all the samples and $\alpha$-tocopherol in $C$. mannii. These oils contained $\alpha, \gamma$ and $\delta$ - tocopherols, with $\gamma$ - tocopherol having the highest levels in these oils. Although $\alpha$-tocopherol is the primary form that presents most biological activities, $\gamma$-tocopherol has 10 to $30 \%$ equivalence of $\alpha$-tocopherol activity. These seeds therefore have antioxidant properties. Their oils could have potential for preventing oxidative stress, tiredness and ageing of cells, hence could play a beneficial role in preventing cancer and degenerative pathologies such as cardiovascular illnesses. These oils (L. siceraria) could be added to palm oil during hot treatment, as antioxidant, to increase its stability by preventing free fatty acids from heat oxidation.

\section{Acknowledgement:-}

This research was supported by the International Foundation for Science, Stockholm, Sweden through a grant to Dr. ACHU Mercy BIH épouse LOH. We are also very grateful to the Institute of Medical Research and Medicinal Plant Studies (IMPM) through the Centre for Research in Food and Nutrition (CRAN) for helping in the analyses of dietary fibre.

\section{References:-}

1. Achu Loh M.B., Madah Silatsa J. and Fokou E. 2016. Antioxidant capacity and mineral contents of five species of Cucurbitaceae seeds from Cameroon. International Journal of Recent Scientific Research, 7 (5): 10961 10970.

2. Achu M.B., Fokou E., Tchiegang C., Fotso M. and Tchouanguep M.F. 2005. Nutritive value of some Cucurbitaceae oilseeds from different regions in Cameroon. African Journal of Biotechnology, 4 (11): 13291334.

3. Akihisa T., Kimura Y., Kasahara Y., Kumaki K., Thakur S., Tamura T. 1997. Phytochemistry; $46,1261$.

4. Anwar F., Mohammad N.A., Othman F. and Saari N. 2011. Inter-varietal variation in the composition of seeds and seed oils from winter melon [Benincasa hispida (thunb.) cogn.] fruit. Pakistan Journal of Botany; 43(4): 2029-2037.

5. AOAC, 1980. Official methods of analysis of the Association of Official Analytical Chemists. 14 Edn., Williams, SW. (Bd.), Washington DC

6. Awada M., Meynier A., Soulage C.O., Viau M., Ribourg L., Hadji L., Debard C., Benoit B., Géloën A., Guichardant M., Lagarde M., Genot C. and Michalski M.C. 2013. N-3 PUFA added to high-fat diets affect 
differently adiposity and inflammation when carried by phospholipids or triacylglycerols in mice. Nutrition and Metabolism, 10: 10-23.

7. Bourgeois C. 2003. Vitamins in agro-business industries. Editions Tec \& DOC, pp. 11, 74. 86 - 90, $274-277$ and $636-656$.

8. Brown I., Rosner B., Willett W.W. and Sacks F.M. 1999. Cholesterol-lowering effects of dietary fiber: A metaanalysis. American Journal of Clinical Nutrition, 69: 30 - 42.

9. Buttriss J.L. and Diplock A.T. 1984. High-performance liquid chromatographic methods for vitamin E in tissues. Methods in Enzymology, 105: 131-138.

10. Chaplin M.F. 2004. The structure of plantago ovota arabinoxylan, gum and stabilisers for the food industry, Ed P. A. Williams and G. 1O. Phillips, Royal Society of Chemistry, 12, 509-516.

11. Etminan M., Gill, S.S. and Samii, A. 2005. Intake of vitamin E, vitamin C, and carotenoids and the risk of Parkinson's disease: A meta-analysis. Lancet Neurology, 4, 362-365.

12. Fokou, E., Achu, M. B., Kansci G., Ponka R., Fotso M., Tchiégang C. and Tchouanguep M. F. 2009. Chemical Properties of some Cucurbitaceae Oils from Cameroon. Pakistan Journal of Nutrition, 8 (9): 1325-1334

13. Folch J., Lees M. and Sloane Stanley G.H. 1957. A simple method for the isolation and purification of total lipids from animal tissues. Journal of Biological Chemistry, 226: 497-509.

14. Fomekong A., Messi J., Kekeunou S., Tchuenguem F.F.N. and Tamesse J.L. 2008. Entomofauna of Cucumeropsis mannii Naudin, its impact on plant yield and some aspects of the biology of Dacusbivitattus (Diptera: Tephritidae). African Journal of Agricultural Research; 3 (5): 363-370.

15. Galisteo M., Duarte J., Zarzuelo A. 2008. Effects of dietary fibers on disturbances clustered in the metabolic syndrome. Journal of Nutritional Biochemistry; 19: 71-84.

16. Gottschalck T.E. and Breslawec H. 2012. International Cosmetic Ingredient Dictionary and Handbook. Washington, DC: Personal Care Products Council.

17. Hanai H., Ikuma M., Sato Y., Lida T., Hosoda Y. and Matsushita I. 1997. Long-term effects of water-soluble corn bran hemicellulose on glucose tolerance in obese and non-obese patients: Improved insulin sensitivity and glucose metabolism in obese subjects. Bioscience, Biotechnology, and Biochemistry, 61:1358 - 1361.

18. Howarth N.C., Saltzman E. and Roberts S.B. 2001. Dietary fiber and weight regulation. Nutrition Review; 59 (5): 129-39

19. Institute of Medicine. 2000. Food and Nutrition Board. Dietary Reference Intakes for Vitamin C, Vitamin E, Selenium and Carotenoids. The National Academies Press. Pp: 237-241.

20. Institute of Medicine. 2005. Dietary Reference Intakes for Energy, Carbohydrate, Fiber, Fat, Fatty Acids, Cholesterol, Protein and Amino Acids (macronutrients). The National Academies Press. Pp: 386 - 390.

21. Jordan F.T.W. and Pattison M. 1996. Poultry Diseases. 4th edition. London, GB. W.B. Saunders Company, 546 p.

22. Kershow S. J. and Hackett F. 1987. Composition of three standard solvent extraction procedures for the determination of oil content in commercial oilseed samples. Journal of the Science of Food and Agriculture; 40 (3): 233-244.

23. Kim M.Y., Kim E. J., Kim Y.N., Choi C. and Lee1 B.H. 2012. Comparison of the chemical compositions and nutritive values of various pumpkin (Cucurbitaceae) species and parts. Nutrition Research and Practice; 6 (1): 21-27

24. Landrier J.F., Gouranton E., Reboul E., Cardinault N., El Yazidi C., Malezet-Desmoulins C., André M., Nowicki M., Souidi M. and Borel P. 2010. Vitamin E decreases endogenous cholesterol synthesis and apo-AImediated cholesterol secretion in Caco-2 cells. Journal of Nutrition and Biochemistry; 21: 1207-1213.

25. Li, F.J., Shen, L. and Ji H.F. 2012. Dietary intakes of vitamin E, vitamin C, and beta-carotene and risk of Alzheimer's disease: A meta-analysis. Journal of Alzheimers Disease, 31, 253-258.

26. Liu S., Willett W.C., Manson J.E., Hu F.B., Rosner B. and Colditz G. 2003. Relation between changes in intakes of dietary fiber and grain products and changes in weight and development of obesity among middleaged women. American Journal of Clinical Nutrition; 78: 920 - 927.

27. Luciani C., Vanni B., Marta C., Diana F., Gabrielle G., Brunella T., Laura Z. and Laura L. (2001). Antioxidants and total peroxyl radical-trapping ability of olive and seed oils. Journal of Agriculture and Food Chemistry, 49 (12): 6026-6032.

28. Mabaleha M.B., Mitei Y.C. and Yeboah S.O. 2007. A comparative study of the properties of selected melon seed oils as potential candidates for development into commercial edible vegetable oils. Journal of the American Oil Chemists' Society; 84, 31-36.

29. Martin A. 2001. The "apports nutritionnels conseillés (ANC)" for the French population. Reproduction Nutrition Development; EDPS Sciences, 41(2): 119-128. 
30. Mathur P., Ding Z., Saldeen T. and Mehta J.L. 2015. Tocopherols in the Prevention and Treatment of Atherosclerosis and Related Cardiovascular Disease. Clinical Cardiology; 38(9): 570-576.

31. Meyer K.A., Kushi L.H. and Jacobs D.R. Jr. 2000. Carbohydrates, dietary fiber and incidence of type 2 diabetes in older women. American Journal of Clinical Nutrition, 71: 921-930.

32. Naziri E., Mitic M.N. and Tsimidou M.Z. 2016. Contribution of tocopherols and squalene to the oxidative stability of cold-pressed pumkin seed oil (Cucurbita pepo L.). European Journal of Lipid Science and Technology; 118, 898-905.

33. Nkanyiso J. S., Albert T.M. and Kirthee P. 2015. An Assessment of minerals and protein contents in elected South African bottle gourd landraces [Lagenaria siceraria (Mol. Standl.)]. Journal of Human Ecology, 51(3): 279-286.

34. Nmila R., Rchid H., Gross R., Manteghetti M., Ribes G., Petit P., Tijane M. and Sauvaire Y. 2002. Mise en évidence d'un effet insulino-stimulant de fractions de graines de coloquinte (Citrullus colocynthis L. Schrader). Biologie \& Santé, 2 (2): 88-99.

35. Pereira M. A., Jacobs D. R., Pins J. J. Raatz S. K. Gross M. D., Slavin J. L. and Seaquist E. R. 2002. Effect of whole grains on isulin sensitivity in overweight hyperinsulinemic adults. American Journal of Clinical Nutrition, 75: $848-855$.

36. Phillips K.M., Ruggio D.M., Ashraf-Khorassani M. 2005. Phytosterol composition of nuts and seeds commonly consumed in the United States. Journal of Agricultural and Food Chemistry; 53: 9436-45.

37. Prosky L., Lee S.C. and DeVries J.W. 1992. Determination of total, soluble, and insoluble, dietary fibre in foods - enzymatic gravimetric method, Phosphate buffer: Collaborative study. Journal of the Association of Official Analytical Chemists; 75: 395-416.

38. Rezig L., Chouaibi M., Msaada K. and Hamdi S. 2012. Chemical composition and profile characterization of pumpkin (Cucurbita maxima) seed oil. Industrial Crops and Products; 37, 82-87.

39. Ripsin C.M., Keenan J.M., Jacobs Jr. D.R., Elmer P.J., Welch R.R., Van Hom L., Liu K., Turnbull W. H. and Kstin M. 1992. Oat products and lipid lowering. A meta-analysis. Journal of American Medical Association, 267: $3317-3325$.

40. Rizvi S., Raza S.T., Ahmed F., Ahmad A., Abbas S., Mahdi F. 2014. The Role of Vitamin E in human health and some diseases. Sultan Qaboos University Medical Journal; 14, (2): 157-165,

41. Ryan E., Galvin K., O'Connor T.P., Maguire A.R. and O'Brien N.M. 2007. Phytosterol, squalene, tocopherol content and fatty acid profile of selected seeds, grains, and legumes. Plant Foods for Human Nutrition, 62: 8591.

42. Sadou S.H., Saadou M. et Claude-Louis L. 2005. Composition chimique globale des graines et caractéristiques physico-chimiques des huiles de Luffa aegyptiaca et de Luffa cylindrica du Niger. Journal de la Société OuestAfricaine de Chimie; $20: 119-133$.

43. Schippers R. 1997. African indigenous vegetables. International Plant Genetic Resources Iinstitute (Editor) Limbé, Cameroon, 93-112p.

44. Shahidi F. and Camargo A. C. 2016. Tocopherols and Tocotrienols in Common and Emerging Dietary Sources: Occurrence, Applications, and Health Benefits. International Journal of Molecular Sciences; 17, 1745; doi: 10.3390/ijms 17101745.

45. Shahidi, F. and Zhong, Y. 2010. Lipid oxidation and improving the oxidative stability. Review. Chemistry of Society; 39, 4067-4079.

46. Stevenson D.G., Eller F.J., Wang L., Jay-Lin J., Wang T. and Inglett G.E. 2007. Oil and tocopherol content and composition of pumpkin seed oils in 12 Cultivars. Journal of Agricultural and Food Chemistry; 55, 4005-4013.

47. Supriyono, Sumardiyono and Pramono R.J. 2016. Application of Tocopherol as antioxidant to reduce decomposition of process on palm oil biodiesel. International journal of Chemical and Molecular Engineering; 10 (7): 944-947.

48. Tafazoli S., Wright J.S. and O'Brien P.J. 2005. Prooxidant and antioxidant activity of vitamin E analogous and troglitazone. Chemistry. Research. Toxicology; 18: 1567 - 1574.

49. Tanya A.K.N., Mbofung C.M.F. and Keshnro O.O. 1997. Soluble and insoluble fibre contents of some Cameroonian foodstuffs. Plant Foods for Human Nutrition ; 51: 199 - 207.

50. Tsai Y.S., Tong Y.C., Cheng J.T., Lee C. H., Yang F.S., Lee H.Y. (2006). Pumpkin seed oil and phytosterol-F can block testosterone/ prazosin-induced prostate growth in rats. Urologia Internationalis, 77: 269-274.

51. Ullah N., Khan S., Khan A., Ahmad W., Shah Y., Ahmad L. and Ullah I. 2015. A Prospective pharmacological review of medicinal herbs, Cucumis melo and Berberis vulgaris, commonly used in the treatment of renal diseases in Pakistan. Acta Poloniae Pharmaceutica - Drug Research; 72 (4): 651-654 
52. World Health Organisation (WHO). 2014. Rapport sur les situations mondiales des maladies nontransmissibles: Profil des pays pour les maladies non transmissibles, Cameroun. www.who.int/nmh/publication/ncd-status-report-2014/fr/ Access date 10/01/2017

53. Zoro Bi I.A., Koffi K.K. and Djé Y. 2003. Caractérisation botanique et agronomique de trois espèces de Cucurbites consommés en sauce en Afrique de l'Ouest : Citrullus sp, Cucumeropsis mannii Naudin et Lagenaria siceraria (Molina) Standl. Biotechnologie, Agronomie, Société et Environnement ; 7 (3) : 189-199. 